Bull. Chem. Soc. Ethiop. 2017, 31(3), 435-444.

ISSN 1011-3924

(c) 2017 Chemical Society of Ethiopia and The Authors

Printed in Ethiopia

DOI: http://dx.doi.org/10.4314/bcse.v31i3.7

\title{
A NOVEL SAMARIUM COMPLEX WITH INTERESTING PHOTOLUMINESCENCE AND SEMICONDUCTIVE PROPERTIES
}

\author{
Ding-Wa Zhang ${ }^{1}$, Wen-Tong Chen ${ }^{1,2,3^{*}}$ and Yin-Feng Wang ${ }^{1}$ \\ ${ }^{1}$ Institute of Applied Chemistry, School of Chemistry and Chemical Engineering, Jinggangshan \\ University, Ji' an, Jiangxi 343009, China \\ ${ }^{2}$ Key Laboratory of Jiangxi Province for Persistant Pollutants Control and Resources Recycle \\ (Nanchang Hangkong University), Nanchang, Jiangxi 330000, China \\ ${ }^{3}$ State Key Laboratory of Structural Chemistry, Fujian Institute of Research on the Structure of \\ Matter, Chinese Academy of Sciences, Fuzhou, Fujian 350002, China
}

(Received May 5, 2016; Revised December 20, 2017; Accepted December 28, 2017)

\begin{abstract}
Sm}\left(\mathrm{H}_{2} \mathrm{O}\right)_{4}\left(\mathrm{NO}_{3}\right)_{3}\right](4,4 \text { '-Hbipy })_{2}\left(\mathrm{NO}_{3}\right)_{2}$ (1) (bipy = bipyridine) has been synthesized via hydrothermal reaction and characterized by X-ray diffraction. The title complex features an isolated structure, based on discrete 4,4'-Hbipy moieties, isolated nitrates and $\left[\mathrm{Sm}\left(\mathrm{H}_{2} \mathrm{O}\right)_{4}\left(\mathrm{NO}_{3}\right)_{3}\right]$ species. The samarium ion is in a distorted bicapped square antiprism environment, coordinated by three bidentate nitrates and four coordination water molecules. The 4,4'-Hbipy moieties, isolated nitrates and $\left[\mathrm{Sm}\left(\mathrm{H}_{2} \mathrm{O}\right)_{4}\left(\mathrm{NO}_{3}\right)_{3}\right]$ species are held together via hydrogen bonds and $\pi \ldots \pi$ interactions to form a 3-D supramolecular framework. Luminescent investigation reveals a strong emission in blue region. Optical absorption spectrum of 1 reveals the presence of an optical gap of $3.60 \mathrm{eV}$.
\end{abstract}

KEY WORDS: Bipyridine, Crystal structure, Fluorescence, Hydrothermal reaction, Samarium

\section{INTRODUCTION}

Fluorescent materials, particularly blue fluorescent materials have gained strong interest because blue fluorescence is one of the key color components required for full-color EL displays and blue fluorescent materials are still rare up to now [1-5]. Recently, 4,4'-bipyridine (bipy) with delocalized $\pi$-electrons of the pyridyl rings obtains increasing attention in preparing light emitting complexes in different technical applications, such as emitting materials for organic light emitting diodes, sensitizers in solar energy conversion, chemical sensors and so forth [6-9]. The ability of bipy to act as a rigid, rod-like organic building block in the self-assembly of coordination frameworks is well-known, such as, acting as a charge-compensating cation, a pillar bonding to inorganic skeletal backbone, an uncoordinated guest molecule and organic template, a bridge connecting two metal complex moieties, or linking a metal and an inorganic framework [10-12]. Comparing with the neutral 4,4'-bipy, 4,4'-Hbipy cation is easier to form supramolecular frameworks through H-bonding. Our recent efforts in synthesizing novel complex have focused largely on the systems containing bifunctional molecule like 4,4'-bipy [13-19].

In this work, we describe the synthesis and characterization of $\left[\mathrm{Sm}\left(\mathrm{H}_{2} \mathrm{O}\right)_{4}\left(\mathrm{NO}_{3}\right)_{3}\right]\left(4,4{ }^{\prime}-\right.$ Hbipy $)_{2}\left(\mathrm{NO}_{3}\right)_{2}$ (1). It should be pointed out that the energy band gap of $\mathbf{1}$ is $3.60 \mathrm{eV}$, suggesting that compound $\mathbf{1}$ is a semiconductor.

*Corresponding author. E-mail:cwtqq@aliyun.com

This work is licensed under the Creative Commons Attribution 4.0 International License 


\section{EXPERIMENTAL}

\section{Materials and measurements}

Infrared spectra were carried out on a PE Spectrum-One FT-IR spectrometer using KBr discs. The UV-Vis spectrum was recorded at room temperature on a computer-controlled PE Lambda $35 \mathrm{UV}-\mathrm{Vis}$ spectrometer equipped with an integrating sphere in the wavelength range 190-1100 $\mathrm{nm} . \mathrm{BaSO}_{4}$ plate was used as a reference $(100 \%$ reflectance), on which the finely ground powder of the samples were coated. The absorption spectrum was calculated from reflection spectra by the Kubelka-Munk function [20]: $\alpha / S=(1-R)^{2} / 2 R, \alpha$ is the absorption coefficient, $S$ is the scattering coefficient which is practically wavelength independent when the particle size is larger than $5 \mu \mathrm{m}$, and $R$ is the reflectance. The fluorescence study was conducted at room temperature on a JY Fluorolog-322 fluorescence spectroscopy instrument. All reactants of A.R. grade were obtained commercially and used without further purification.

\section{Synthesis of complex 1}

$\mathrm{Sm}\left(\mathrm{NO}_{3}\right)_{3} \cdot 6 \mathrm{H}_{2} \mathrm{O}(0.5 \mathrm{mmol}, 222 \mathrm{mg}), 4,4^{\prime}$-bipy( $\left.1 \mathrm{mmol}, 156 \mathrm{mg}\right), \mathrm{HNO}_{3}$ acid $(1 \mathrm{~mL})$ and distilled water $(10 \mathrm{~mL})$ were loaded into a Teflon-lined stainless steel autoclave $(25 \mathrm{~mL})$ and kept at $423 \mathrm{~K}$ for 10 days. After being slowly cooled to room temperature at a rate of $5 \mathrm{~K} / \mathrm{h}$, yellow crystals suitable for X-ray analysis were obtained. Yield: $61 \%$ (based on samarium). FTIR peaks $\left(\mathrm{KBr}, \mathrm{cm}^{-1}\right)$ : 3447(m), 3063(m), 2462(w), 1950(w), 1847(w), 1613(vs), 1537(m), 1492(m), 1419(s), 1320(w),1222(s), 1074(s), 1049(m), 1015(m), 862(w), 813(vs), 729(m), 641(s), 567(w) and 498(m).

\section{$X$-ray data collection and structure refinement}

X-ray diffraction data were collected on Rigaku Mercury CCD X-ray diffractometer with graphite monochromated Mo- $K \alpha$ radiation $(\lambda=0.71073 \AA)$ using a $\omega$ scan technique. Crystal Clear software was used for data reduction and empirical absorption correction. The structure was solved by the direct methods using the Siemens SHELXTL $^{\mathrm{TM}}$ Version 5 package of crystallographic software. The difference Fourier maps based on the atomic positions yield all non-hydrogen atoms. The structure was refined using a full-matrix least-squares refinement on $F^{2}$. All non-hydrogen atoms were refined anisotropically. The positions of hydrogen atoms were generated theoretically, allowed to ride on their respective parent atoms and included in the structure factor calculations with assigned isotropic thermal parameters but not refined. The summary of crystallographic data and structure analysis is given in Table 1 . The selected bond lengths are listed in Table 2. Crystallographic data for the structural analysis have been deposited with the Cambridge Crystallographic Data Centre, CCDC No. 686904. Copies of this information may be obtained free of charge from the Director, CCDC, 12 Union Road, Cambridge, CBZ 1EZ, UK (Fax: +44-1223-336033; email: deposit@ccdc.cam.ac.uk or www:http://www.ccdc. cam.ac.uk).

\section{RESULTS AND DISCUSSION}

\section{FT-IR spectroscopy}

As for the title complex, its FT-IR bands are dominantly resided in the frequency range of $498-1613 \mathrm{~cm}^{-1}$. The band at $3447 \mathrm{~cm}^{-1}$ could be ascribed to the $v_{\mathrm{O}-\mathrm{H}}$ stretching vibration of the water molecules, while the band at $3063 \mathrm{~cm}^{-1}$ could be assigned to the $v_{\mathrm{C}-\mathrm{H}}$ bent vibration mode 
of the 4,4'-bipyridinium moieties. The strong intensity band locating at $1222 \mathrm{~cm}^{-1}$ could be attributed to the stretching mode of the pyridyl rings of the 4,4'-bipyridiniummoieties. The band at $1074 \mathrm{~cm}^{-1}$ could be ascribed to the $\delta_{\mathrm{C}-\mathrm{H}}$ stretching vibration. The bands locating at the $641-1049 \mathrm{~cm}^{-1}$ region could be corresponded to the aromatic ring bending modes of the 4,4'bipyridinium moieties. Two bands at $567 \mathrm{~cm}^{-1}$ and $498 \mathrm{~cm}^{-1}$ could be ascribed to the $v_{\mathrm{Sm}-\mathrm{O}}$ stretching vibration.

Table 1. Crystal data of $\left[\mathrm{Sm}\left(\mathrm{H}_{2} \mathrm{O}\right)_{4}\left(\mathrm{NO}_{3}\right)_{3}\right]\left(4,4^{\prime}-\mathrm{Hbipy}\right)_{2}\left(\mathrm{NO}_{3}\right)_{2}$.

\begin{tabular}{|l|l|}
\hline Empirical formula & $\mathrm{C}_{20} \mathrm{H}_{26} \mathrm{~N}_{9} \mathrm{O}_{19} \mathrm{Sm}$ \\
\hline Formula weight & 846.85 \\
\hline Crystal system & Triclinic \\
\hline Space group & $P_{-1}$ \\
\hline Unit cell dimensions & $a=8.1141(5) \AA$ \\
& $b=12.7860(8) \AA$ \\
& $c=15.1511(9) \AA$ \\
& $\alpha=95.050(1)^{\circ}$ \\
& $\beta=101.689(1)^{\circ}$ \\
\hline$Z$ & $\gamma=100.066(1)^{\circ}$ \\
\hline$V$ & 2 \\
\hline$D_{\mathrm{x}}$ & $1503.1(2) \AA^{3}$ \\
\hline Absorption coefficient & $1.871 \mathrm{Mg} / \mathrm{m}^{3}$ \\
\hline Crystal size & $2.054 \mathrm{~mm}{ }^{-1}$ \\
\hline No. of reflections collected/unique & $0.48 \times 0.42 \times 0.27 \mathrm{~mm}$ \\
\hline Goodness-of-fit on $F^{2}$ & $9041 / 4903\left[R_{\text {(int) }}=0.0184\right]$ \\
\hline Final $R$ indices & 1.095 \\
\hline$R$ indices (all data) & $R_{1}=0.0251, w R_{2}=0.0645$ \\
\hline Index ranges & $R_{1}=0.0283, w R_{2}=0.0656$ \\
\hline$(\Delta / \sigma)_{\text {max }}$ & $-9 \leq h \leq 9,-15 \leq k \leq 15,-18 \leq l \leq 18$ \\
\hline & 0.001 \\
\hline
\end{tabular}

Table 2. Selected bond lengths of $\mathbf{1}$.

\begin{tabular}{|l|l|l|l|}
\hline $\mathrm{Sm}(1)-\mathrm{O}(1 \mathrm{~W})$ & $2.424(2)$ & $\mathrm{Sm}(1)-\mathrm{O}(2)$ & $2.493(2)$ \\
\hline $\mathrm{Sm}(1)-\mathrm{O}(2 \mathrm{~W})$ & $2.429(2)$ & $\mathrm{Sm}(1)-\mathrm{O}(4)$ & $2.564(2)$ \\
\hline $\mathrm{Sm}(1)-\mathrm{O}(3 \mathrm{~W})$ & $2.427(2)$ & $\mathrm{Sm}(1)-\mathrm{O}(5)$ & $2.509(2)$ \\
\hline $\mathrm{Sm}(1)-\mathrm{O}(4 \mathrm{~W})$ & $2.479(2)$ & $\mathrm{Sm}(1)-\mathrm{O}(7)$ & $2.598(2)$ \\
\hline $\mathrm{Sm}(1)-\mathrm{O}(1)$ & $2.797(3)$ & $\mathrm{Sm}(1)-\mathrm{O}(8)$ & $2.531(2)$ \\
\hline
\end{tabular}

\section{Crystal structure of 1}

An ORTEP drawing of $\mathbf{1}$ is shown in Figure 1. X-ray diffraction analysis reveals that the title complex features an isolated structure, consisting of two 4,4'-Hbipy moieties, two isolated nitrates and one $\left[\mathrm{Sm}\left(\mathrm{H}_{2} \mathrm{O}\right)_{4}\left(\mathrm{NO}_{3}\right)_{3}\right]$ species. The samarium atom is in a distorted bicapped square antiprism environment, coordinated by three bidentate nitrates and four coordination water molecules (Figure 1). The bond lengths of $\operatorname{Sm}(1)-\mathrm{O}(1 \mathrm{~W}), \operatorname{Sm}(1)-\mathrm{O}(2 \mathrm{~W}), \mathrm{Sm}(1)-\mathrm{O}(3 \mathrm{~W})$ and $\mathrm{Sm}(1)-\mathrm{O}(4 \mathrm{~W})$ are 2.424(2), 2.429(2), 2.427(2) and 2.479(2) $\AA$, respectively, with an average value of 2.439(2) $\AA$ which is comparable with those reported [21-25]. In the three bidentate nitrate groups, the $\mathrm{Sm}-\mathrm{O}_{\text {nitrate }}$ distances range from 2.493(2) to 2.797(3) $\AA$ (Table 2) with a mean value of $2.582(3) \AA$. The $\mathrm{Sm}-\mathrm{O}_{\text {nitrate }}$ distances are comparable with those reported in the literature [26-30]. The average bond length of $\mathrm{Sm}-\mathrm{O}_{\text {water }}$ is obviously shorter than that of $\mathrm{Sm}-\mathrm{O}_{\text {nitrate }}$, indicating that water has a stronger affinity to $\mathrm{Sm}^{\mathrm{III}}$ ion than that of nitrate. 


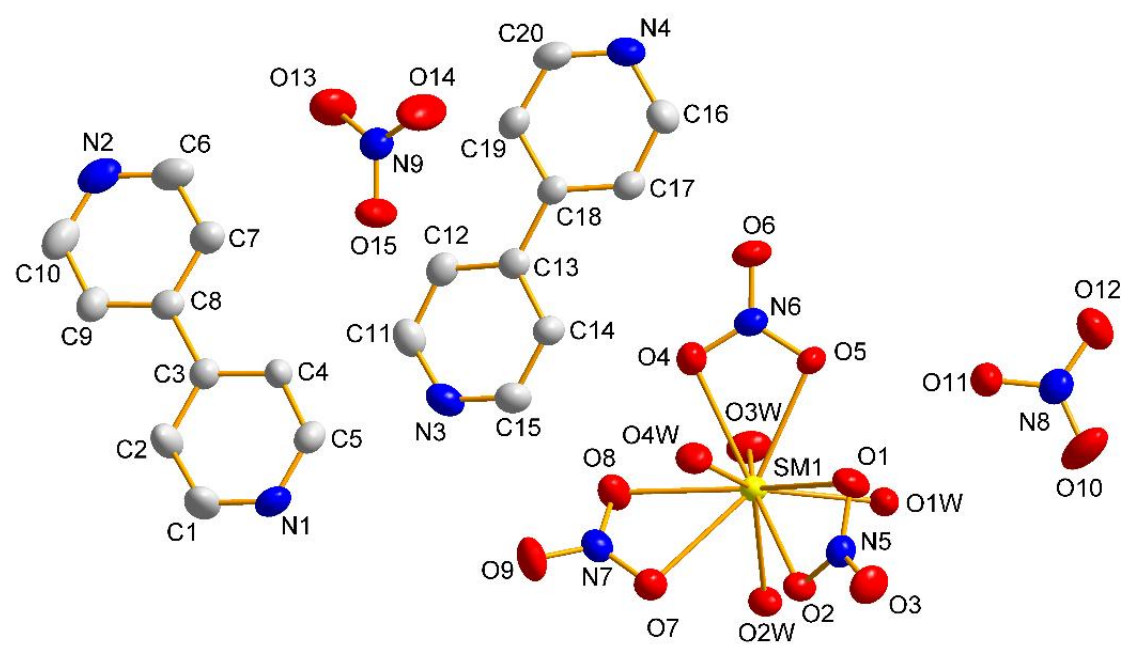

Figure 1. ORTEP drawing of $\mathbf{1}$ with 50\% thermal ellipsoids. Hydrogen atoms were omitted for clarity.

There are two kinds of 4,4'-Hbipy moieties in the title complex. For one of them, the two pyridyl rings are twisted with a dihedral angle of $c a .3 .91^{\circ}$, which is comparable with that previously documented $[31,32]$; For another, the two pyridyl rings have a larger dihedral angle of $c a .14 .75^{\circ}$, comparable with that previously documented [33-35]. In the title complex, some weak $\pi \ldots \pi$ stacking interactions are established between the 4,4'-Hbipy moieties. The rings of the $4,4^{\prime}$-Hbipy moieties involved in the $\pi \ldots \pi$ stacking interactions are arranged in such a way that the six atoms of each ring do not completely eclipse those of the other ring, meaning that the interaction is not "perfect face alignment" but "offset or slipped stacking".

For clarity, we define the pyridyl rings involved into the $\pi \ldots \pi$ stacking interactions as R1, R2 and R3, containing N2, N3 and N4 atoms, respectively. The R1 ring in one 4,4'-Hbipy moiety has a $\pi \ldots \pi$ contact with a R1' ring in one adjacent 4,4'-Hbipy moiety; the R2 and R3 rings in one 4,4'-Hbipy moiety connects to a R3' and R2' ring in another adjacent 4,4'-Hbipy moiety via $\pi \ldots \pi$ interaction. The centroid-to-centroid distance is $3.936 \AA$ for rings $\mathrm{R} 1$ and $\mathrm{R} 1{ }^{\prime}$, while it is $3.785 \AA$ from $\mathrm{R} 2$ to $\mathrm{R} 3^{\prime}$ or $\mathrm{R} 3$ to $\mathrm{R} 2^{\prime}$. The perpendicular distance from $\mathrm{R} 1$ to $\mathrm{R} 1^{\prime}$ is $3.473 \AA$, while it is $3.608 \AA$ from $\mathrm{R} 2$ to $\mathrm{R} 3^{\prime}$ or $\mathrm{R} 3$ to $\mathrm{R} 2^{\prime}$.R 1 slides from $\mathrm{R} 1^{\prime}$ for about $1.852 \AA$, while R2 slides from R3' or R3 slides from R2' for about $1.143 \AA$. The dihedral angle is $0.02^{\circ}$ between R1 and R1' while it is $14.75^{\circ}$ between R2 and R3' or R3 and R2'. The $\left[\mathrm{Sm}\left(\mathrm{H}_{2} \mathrm{O}\right)_{4}\left(\mathrm{NO}_{3}\right)_{3}\right]$ species interconnect to each other via $\mathrm{O}(3 \mathrm{~W}) \ldots \mathrm{O}(3)$ hydrogen bonds to yield a chain. The 4,4'-Hbipy moieties containing rings R2 and R3 link two such chains to form a ladder like structure through hydrogen bonds and $\pi \ldots \pi$ contacts (Figure 2 ). The isolated nitrates and 4,4'-Hbipy moieties containing ring R1 bridge two neighboring 'ladders' via hydrogen bonds to give a 2-D layer. The 2-D layers are further interconnected via hydrogen bonds and $\pi \ldots \pi$ contacts to construct a 3 -D supramolecular framework (Figure 2).

\section{Photoluminescence properties}

The solid-state emission spectra of the title complex are investigated at room temperature. The emission spectrum of the title complex is given in Figure 3. The fluorescent spectrum study shows that the title complex exhibits a broad and strong blue-light emission band with a 
maximum wavelength of $457 \mathrm{~nm}$ upon photo-excitation at $366 \mathrm{~nm}$. The luminescent spectra of pure bipy were also measured under the same condition. For pure bipy, the emission spectra show one intense emission band in blue region with the maximum wavelength of $438 \mathrm{~nm}$ upon photo-excitation at $357 \mathrm{~nm}$ (inner plot of Figure 3). Thus, this complex may be a candidate in blue-light luminescent materials.

A search from the Cambridge Crystallographic Data Centre (CCDC) shows that there are dozens of complexes containing samarium [36-40]. However, among these complexes, only several are samarium-containing complex with bipy [41-45].

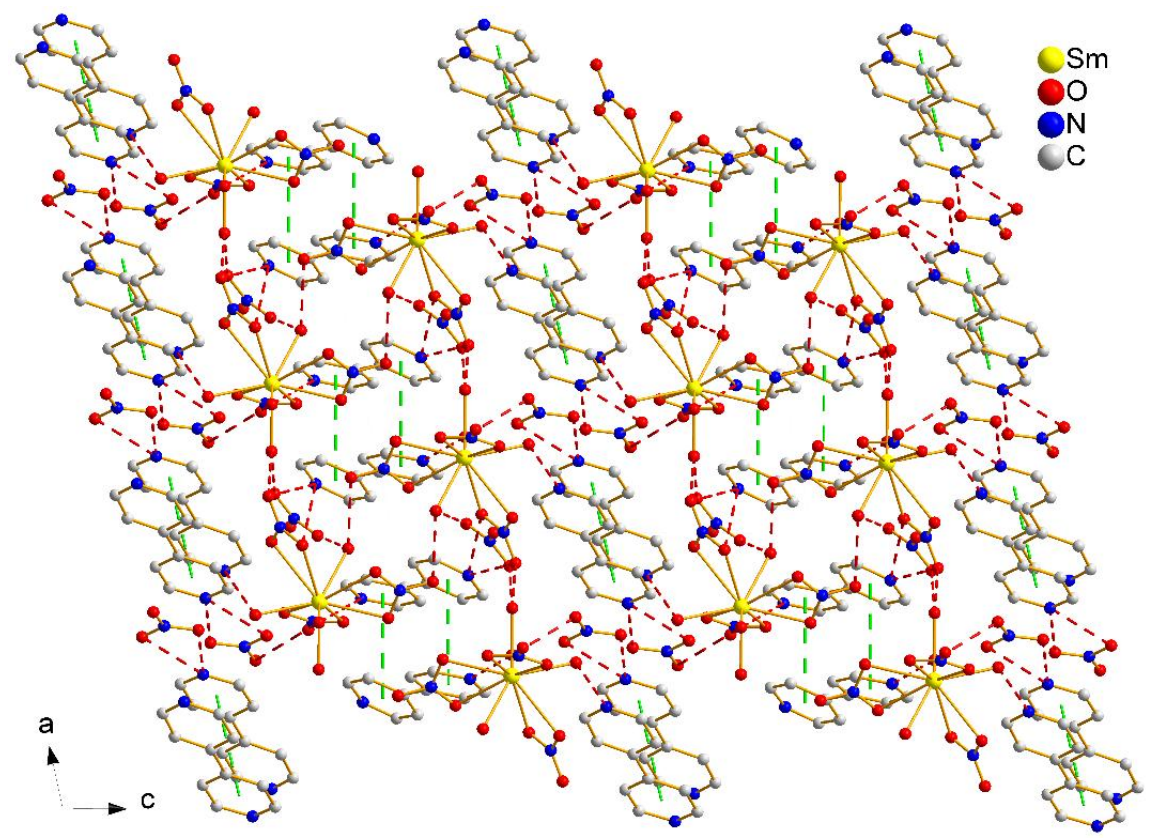

Figure 2. Packing diagram of $\mathbf{1}$ with the green and red dashed lines representing $\pi \ldots \pi$ interactions and hydrogen bonds, respectively. Hydrogen bonds $(\AA ̊)$ : O1W...N1(-x, -y, z) 2.786(4), O2W...N4(x, -1+y, z) 2.763(4), O2W...O10(1-x, -y, 1-z) 2.934(4), O3W...O3(1+x, y, z) 2.898(4), O3W...O13(1-x, 1-y, -z) 2.742(4), O4W...O14(-x, 1-y, z) 2.681(4), O4W...O9(-x, -y, -z) 2.878(4), O2...N3(-x, -y, -z) 2.994(4), O3...N3(-x, -y, -z) 2.963(4), O11...N2(1-x, 1-y, -z) 2.796(4) and O12...N2(1-x, 1-y, -z) 3.040(4).

\section{Semiconductive properties}

Optical absorption spectrum of complex 1 discovers the presence of a wide optical band gap of $3.60 \mathrm{eV}$ (Figure 4), which indicates that complex 1is a potential semiconductor and this is consistent with the color of the crystals $[46,47]$. The steep slope of the optical absorption edges for complex1 is indicative of the existence of direct transitions [48]. It should be pointed out that the energy band gap of $3.60 \mathrm{eV}$ of complex 1is obviously larger than those of CuInS $\mathrm{C}_{2}(1.55 \mathrm{eV})$, CdTe $(1.5 \mathrm{eV}), \mathrm{CuInSe}_{2}(1.04 \mathrm{eV})$, and $\mathrm{GaAs}(1.4 \mathrm{eV})$, all of them are highly efficient photovoltaic materials [49-50]. The wide optical band gap of $3.60 \mathrm{eVof}$ complex 1 is probably because of the 4,4'-Hbipy moieties which is an organic ligand and can enlarge the optical band gap. 


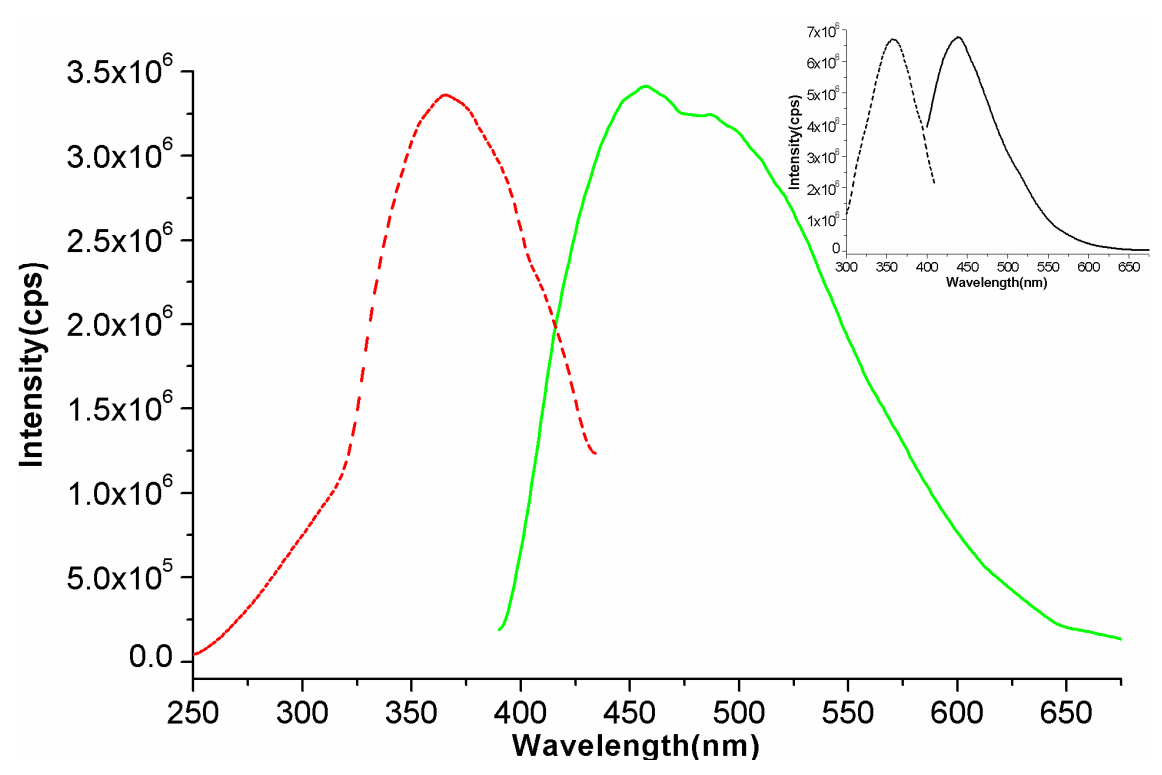

Figure 3. Solid-state emission and excitation spectra of 1 at room temperature (Inner plot: pure bipy). Solid line: emission spectrum; dashed line: excitation spectrum.

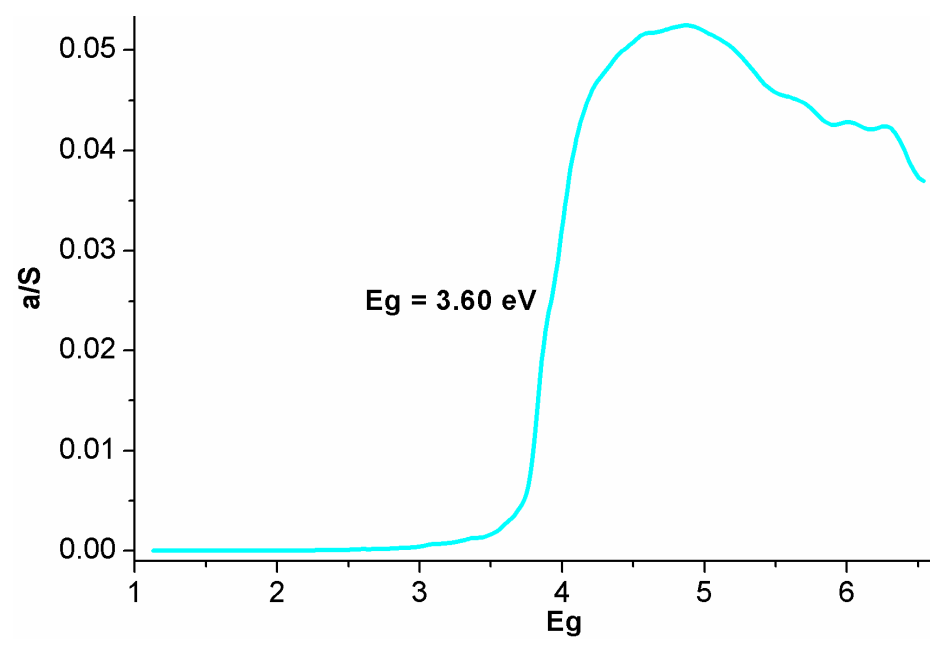

Figure 4. Solid-state diffuse reflectance spectrum of $\mathbf{1}$.

\section{CONCLUSION}

In brief, a new complex, $\left[\mathrm{Sm}\left(\mathrm{H}_{2} \mathrm{O}\right)_{4}\left(\mathrm{NO}_{3}\right)_{3}\right](4,4 \text { '-Hbipy })_{2}\left(\mathrm{NO}_{3}\right)_{2}(\mathbf{1})$, has been synthesized via hydrothermal reaction. It should be pointed out that the energy band gap of $\mathbf{1}$ is $3.60 \mathrm{eV}$, 
suggesting that compound $\mathbf{1}$ is a wide optical band gap semiconductor. This complex exhibits a broad and strong fluorescent emission band, and it may be used as a blue-light material. Further investigations on this field are in progress in our laboratory.

\section{ACKNOWLEDGEMENTS}

We gratefully acknowledge the financial support of the NSF of China $(21565016,21361013)$, Jiangxi Provincial Science and Technology Support Key Project(20152ACG70021), Jiangxi Provincial Natural Science Foundation(20142BAB205062), Jiangxi Provincial Department of Education's Item of Science and Technology(GJJ150761, GJJ14557), Jinggangshan University Natural Science Item (JZ0813), the open foundation (ST201522007) of the Key Laboratory of Jiangxi Province for Persistant Pollutants Control and Resources Recycle (Nanchang Hangkong University), and the open foundation (20150019) of the State Key Laboratory of Structural Chemistry, Fujian Institute of Research on the Structure of Matter, Chinese Academy of Sciences.

\section{REFERENCES}

1. Wang, J.; Liu, H.B.; Tong, Z.; Ha, C.S. Fluorescent/luminescent detection of natural amino acids by organometallic systems. Coord. Chem. Rev. 2015, 303, 139-184.

2. Sfrazzetto, G.T.; Satriano, C.; Tomaselli, G.A.; Rizzarelli, E. Synthetic fluorescent probes to map metallostasis and intracellular fate of zinc and copper. Coord. Chem. Rev. 2016, 311, 125-167.

3. Tigineh, G.T.; Liu, L.-K. A simple and facile colorimetric chemosensor for selective detection of $\mathrm{Cu}^{2+}$ ion in aqueous solution. Bull. Chem. Soc. Ethiop. 2017, 31, 31-38.

4. Karslioglu, S.; Demir, S.; Yilmaz, H.; Gorduk, S. A rational synthesis of a novel imidazo[4,5-f][1,10] phenanthroline templated Schiff base: Characterization, photoluminescence and DFT/TD-DFT study. Bull. Chem. Soc. Ethiop. 2017, 31, 137-147.

5. Gai, L.; Mack, J.; Lu, H.; Nyokong, T.; Li, Z.; Kobayashi, N.; Shen, Z. Organosilicon compounds as fluorescent chemosensors for fluoride anion recognition. Coord. Chem. Rev. 2015, 285, 24-51.

6. Irwin, M.; Krämer, T.; McGrady, J.E.; Goicoechea, J.M. On the structural and electronic properties of $\left[\mathrm{Zn}_{2}\left(4,4^{\prime} \text {-bipyridine }\right)(\mathrm{mes})_{4}\right]_{\mathrm{n}^{-}}(\mathrm{n}=0-2)$, a homologous series of bimetallic complexes bridged by neutral, anionic, and dianionic 4,4'-bipyridine. Inorg. Chem. 2011, 50, 5006-5014.

7. Ohmura, T.; Morimasa, Y.; Suginome, M. Organocatalytic diboration involving "reductive addition" of a boron-boron $\sigma$-bond to 4,4'-bipyridine. J. Am. Chem. Soc. 2015, 137, 28522855.

8. Ranjan, R.; Olson, J.; Singh, P.; Lorance, E.D.; Buttry, D.A.; Gould, I.R. Reversible electrochemical trapping of carbon dioxide using 4,4'-bipyridine that does not require thermal activation. J. Phys. Chem. Lett. 2015, 6, 4943-4946.

9. Surov, A.O.; Simagina, A.A.; Manin, N.G.; Kuzmina, L.G.; Churakov, A.V.; Perlovich, G.L. Fenamate cocrystals with 4,4'-bipyridine: structural and thermodynamic aspects. Cryst. Growth. Des. 2015, 15, 228-238.

10. Giménez-Marqués, M.; Hidalgo, T.; Serre, C.; Horcajada, P. Nanostructured metal-organic frameworks and their bio-related applications. Coord. Chem. Rev. 2016, 307, 342-360.

11. Li, B.; Chrzanowski, M.; Zhang, Y.; Ma, S. Applications of metal-organic frameworks featuring multi-functional sites. Coord. Chem. Rev. 2016, 307, 106-129.

12. Abaszadeh, M.; Seifi, M.; Ebrahimipour, S.Y. Two ligand oxidio-vanadium(IV) complexes as novel efficient catalysts in multicomponent reactions for synthesis of tetrahydrobenzopyran derivatives. Bull. Chem. Soc. Ethiop. 2016, 30, 253-262. 
13. Chen, W. Synthesis and structure of a cadmium 4,4'-bipyridine compound. Journal of Jinggangshan University 2014, 35, 38-41.

14. Chen, W.; Chen, H.; Kuang, H. In situ preparation,crystal structure and fluorescence of $\left[\left(\mathrm{CH}_{3}\right)_{2}-4,4^{\prime}-\mathrm{H}_{2}\right.$ bipy $]\left[\mathrm{FeCl}_{4}\right]_{2}($ Bipy $=$ Bipyridine). Synth. React. Inorg. Mater. 2014, 44, $130-$ 132.

15. Yao, Z.; Chen, W.; Hu, R. Photoluminescence and theoretical study of $\left[{ }_{1}^{\infty}\left(\mathrm{Cd}_{2} \mathrm{Cl}_{6}\right)\right]\left[2\left(\mathrm{CdCl}_{4}\right)\right]\left[3\left(\mathrm{~N}, \mathrm{~N}^{\prime}\right.\right.$-dimethyl-4,4'-bipyridinium $\left.)\right]$. Indian J. Chem. A 2015, 54, 489-493.

16. Chen, W.; Hu, R.; Luo, Z.; Chen, H.; Zhang, X.; Liu, J. [N-ethyl-4,4'-bipyridinium][ZnX $\left.{ }_{4}\right]$ $(\mathrm{X}=\mathrm{Cl}$ or $\mathrm{Br}$ ) with $\mathrm{N}$-ethyl-4,4'-bipyridinium generated in situ: Syntheses, structures, fluorescence and TDDFT calculations. Chinese J. Struc. Chem. 2014, 33, 1141-1146.

17. Chen, W.; Hu, R.; Wang, Y.; Zhang, X.; Liu, J. In situ syntheses of two viologen(4,4'bipyridinium)-based cadmium compounds: Structures, fluorescence and theoretical investigations. J. Iran. Chem. Soc. 2014, 11, 1649-1657.

18. Yao, Z.; Chen, W.; Hu, R. Synthesis, structure, properties and computational study of a novel dumbbell-like zinc compound based on 2,2'-biimidazole and 4,4'-bipyridine mixed ligands. Z. Kristallogr. 2015, 230, 139-143.

19. Chen, W.; Hu, R.; Luo, Z.; Chen, H.; Zhang, X.; Liu, J. In situ preparation, structure, fluorescence and TDDFT calculation of $\left[\left(\mathrm{CdCl}_{3}\right)_{2}\left(\mu_{2}-\mathrm{HCl}\right)\right]_{2}\left[\mathrm{CdCl}_{4}(\mathrm{HCl})\right]\left[\mathrm{N}, \mathrm{N}^{\prime}\right.$-dimethyl4,4'-bipyridinium] $]_{3}$. Indian J. Chem. A 2014, 53, 294-298.

20. Kortüm, G. Reflectance Spectroscopy, Springer Verlag: New York; 1969.

21. Wang, X.; Jiang, Z.; Chen, J.; Feng,Y. Lanthanide complexes with disulfide ligand generated in situ: Syntheses, crystal structures and fluorescent properties. Inorg. Chim. Acta 2011, 373, 270-275.

22. Wu, M.; Jiang, F.; Zhou, Y.; Feng, R.; Chen, L.; Hong, M. Photoluminescences and 1D chain-like structures with dinuclear lanthanide(III) units featuring bipyridinetetracarboxylate. Inorg. Chem. Commun. 2012, 15, 25-28.

23. Liu, G.; Zhou, H.; Zha, X.; Zhang, C.; Wang, Y.; Nishihara, S.; Ren, X. Syntheses, crystal structures and physical properties of two unusual $4 \mathrm{~d}-4 \mathrm{f}$ heterometallic coordination polymers. Inorg. Chim. Acta 2012, 387, 308-313.

24. Zhang, H.; Fan, R.; Zhou, G.; Wang, P.; Yang, Y. Syntheses, structures, and luminescent properties of three novel two-dimensional lanthanide coordination polymers with mixed aromatic carboxylate ligands. Inorg. Chem. Commun. 2012, 16, 100-103.

25. Meng, H.; Chen, Y.; Liu, M.; Liu, D.; Zhang, Z.; Zhang, C.; Liu, S. Synthesis, structure and properties of three-dimensional organic-inorganic hybrids based on $\alpha$-metatungstate. Inorg. Chim. Acta 2012, 387, 8-14.

26. Song, X.; Wang, L.; Zhao, M.; Cheng, G.; Wang, X.; Peng, Y. Synthesis, crystal structure and luminescence properties of homodinuclear lanthanide complexes with a new tetrapodal thenylsalicylamide ligand. Inorg. Chim. Acta 2013, 402, 156-164.

27. Visinescu, D.; Toma, L.M.; Fabelo, O.; Ruiz-Perez, C.; Lloret, F.; Julve, M. Lowdimensional 3d-4f complexes assembled by low-spin $\left[\mathrm{FeIII}(\mathrm{phen})(\mathrm{CN})_{4}\right]$-anions. Inorg. Chem. 2013, 52, 1525-1537.

28. Song, X.; Xing, D.; Lei, Y.; Zhao, M.; Cheng, G.; Wang, X.; Peng, Y. Lanthanide coordination polymers constructed by a new semi rigid bridging salicylamide ligand: Synthesis, supramolecular structure and luminescence properties. Inorg. Chim. Acta 2013, 404, 113-122.

29. Stojanovic, M.; Robinson, N.J.; Chen, X.; Sykora, R.E. Reduction of structural dimensionality through incorporation of auxiliary ligands in lanthanide tetracyanoplatinates. Inorg. Chim. Acta 2011, 370, 513-518. 
30. Ding, L.; Jin, W.; Chu, Z.; Chen, L.; Lu, X.; Yuan, G.; Song, J.; Fan, D.; Bao, F. Bulk solvent-free melt ring-opening polymerization (ROP) of L-lactide catalyzed by $\mathrm{Ni}(\mathrm{II})$ and $\mathrm{Ni}(\mathrm{II})-\mathrm{Ln}(\mathrm{III})$ complexes based on the acyclic Salen-type Schiff-base ligand. Inorg. Chem. Commun. 2011, 14, 1274-1278.

31. Wang, C.; Lii, K. Copper uranyl phosphate and arsenate incorporating an organic ligand with a pillared layer structure: $\left[\mathrm{Cu}\left(4,4^{\prime}-\right.\right.$ bpy $\left.)\left(\mathrm{UO}_{2}\right) 0.5\left(\mathrm{HPO}_{4}\right)\left(\mathrm{H}_{2} \mathrm{PO}_{4}\right)\right] \cdot \mathrm{H}_{2} \mathrm{O}$ and $\left[\mathrm{Cu}\left(4,4^{\prime}-\right.\right.$ bpy) $\left.\left(\mathrm{UO}_{2}\right) 0.5\left(\mathrm{HAsO}_{4}\right)\left(\mathrm{H}_{2} \mathrm{AsO}_{4}\right)\right] \cdot 1.5 \mathrm{H}_{2} \mathrm{O}$. J. Solid State Chem. 2013, 197, 456-459.

32. Xiao, S.; Li, X.; Zheng, X.; Jia, T.; Jin, L. 4,4'-Bipyridine-aided synthesis and characterization of $\mathrm{Zn}(\mathrm{II})$ and $\mathrm{Cd}(\mathrm{II})$ 2-sulfoterephthalate complexes. J. Solid State Chem. 2013, 205, 71-81.

33. Shi, S.; Xu, Z.; Teng, H.; Zhao, L.; Cui, X.; Xu, J. Two new compounds constructed from polyoxoanions, metal ions and organic ligands. Inorg. Chim. Acta 013, 402, 123-127.

34. Wu, J.; Wang, F.M.; Liu, J.Q.; Chen, J.X.; Wu, J.M.; Li, K.B.; Wei, Y.; Li, Q.L. Two new 1d coordination polymers: Syntheses, structures and properties. Bull. Chem. Soc. Ethiop. 2014, 28, 415-422.

35. Toncheva, G.K.; Gavazov, K.B.; Georgieva, Z.G.; Dospatliev, L.K.; Peltekov, A.B.; Boyanov, B.S. Application of 4-(2-pyridylazo)resorcinol for flotation-spectrophotometric determination of iron. Bull. Chem. Soc. Ethiop. 2016, 30, 325-332.

36. Song, X.; Wang, L.; Zhao, M.; Cheng, G.; Wang, X.; Peng, Y. Synthesis, crystal structure and luminescence properties of homodinuclear lanthanide complexes with a new tetrapodal thenylsalicylamide ligand. Inorg. Chim. Acta 2013, 402, 156-164.

37. Wu, G.; Wang, X.; Guo, L.; Li, H.; Liu, G. Synthesis, structure and properties of a twodimensional samarium(III) complex of 1,3-benzenedicarboxylic acid and 1,10phenanthroline. Chinese J. Struc. Chem. 2013, 32, 564-570.

38. Shulgin, V.F.; Konnik, O.V.; Abkhairova, S.V.; Gusev, A.N.; Meshkova, S.B.; Kiriyak, A.V.; Rusanov, E.B.; Hasegawa, M.; Linert, W. Anionic lanthanide complexes with 3methyl-1-phenyl-4-formylpyrazole-5-one and hydroxonium as counter ion. Inorg. Chim. Acta 2013, 402, 33-38.

39. Gao, J.; Xiong, X.; Chen, C.; Xie, W.; Ran, X.; Yue, S.; Liu, Y.; Cai, Y. Effect of lanthanide contraction on structures of 3D lanthanide organic frameworks from 5-nitroisophthalic acid and picolinic acid. Inorg. Chem. Commun. 2013, 31, 5-12.

40. Chen, R.; Tang, W.; Jiang, W.; Zhang, Y.; Jia, D. Effect of lanthanide contraction on the Ln /Sb/Se/dien system: Solvothermal syntheses and characterizations of lanthanide(III)selenidoantimonate complexes with diethylenetriamine as a co-ligand. J. Coord. Chem. 2013, 66, 650-661.

41. Weakley, T.J.R. The crystal structures of three adducts of lanthanide nitrates, water and 4,4'bipyridyl: $\left[\mathrm{La}_{2}\left(\mathrm{H}_{2} \mathrm{O}\right)_{7}\left(\mathrm{NO}_{3}\right)_{6}\right] \cdot 4 \mathrm{C}_{10} \mathrm{H}_{8} \mathrm{~N}_{2}$, [ $\left.\mathrm{Ho}\left(\mathrm{H}_{2} \mathrm{O}\right)_{3}\left(\mathrm{NO}_{3}\right)_{3}\right] \cdot 2 \mathrm{C}_{10} \mathrm{H}_{8} \mathrm{~N}_{2}$ and $\left[\mathrm{Y}\left(\mathrm{H}_{2} \mathrm{O}\right)_{3}\left(\mathrm{NO}_{3}\right)_{3}\right]$ $.2 \mathrm{C}_{10} \mathrm{H}_{8} \mathrm{~N}_{2}$. Inorg. Chim. Acta 1982, 63, 161-168.

42. Bo, Q.; Sun, G.; Geng, D. Novel three-dimensional pillared-layer Ln(III)-Cu(I) coordination polymers featuring spindle-shaped heterometallic building units. Inorg. Chem. 2010, 49, 561-571.

43. Yin, X.; Fan, J.; Wang, Z.; Zhang, W. Synthesis, crystal structures, and photoluminescence of lanthanide coordination polymers with 4-acetamidobenzoate. Z. Anorg. Allg. Chem. 2011, 637, 773-777.

44. Yotnoi, B.; Rujiwatra, A.; Reddy, M.L.P.; Sarma, D.; Natarajan, S. Lanthanide sulfate frameworks: Synthesis, structure, and optical properties. Cryst, Growth Des. 2011, 11, $1347-$ 1356.

45. Zhang, Z.; Chen, S.; Mi, J.; He, M.; Chen, Q.; Wu, Z.; Hu, Z. 3-D pillared clay mimics of lanthanide-organic frameworks constructed from 5-fluoroisophthalic acid and 4,4'-bipyridine through hydrogen bonds. Inorg. Chem. Commun. 2010, 13, 1435-1438. 
46. Choi, K.S.; Kanatzidis, M.G. Sulfosalts with alkaline earth metals. Centrosymmetric vs. acentric interplay in $\mathrm{Ba}_{3} \mathrm{Sb}_{4} \cdot 66 \mathrm{~S}_{10}$ and $\mathrm{Ba}_{2} \cdot 62 \mathrm{~Pb} 1.38 \mathrm{Sb}_{4} \mathrm{~S}_{10}$ based on the $\mathrm{Ba} / \mathrm{Pb} / \mathrm{Sb}$ ratio. phases related to arsenosulfide minerals of the rathite group and the novel polysulfide $\mathrm{Sr}_{6} \mathrm{Sb}_{6} \mathrm{~S}_{17}$. Inorg. Chem. 2000, 39, 5655-5662.

47. Aitken, J.A.; Chondroudis, K.; Young, V.G.; Kanatzidis, M.G. LiEuPSe4 and KEuPSe4: Novel selenophosphates with the tetrahedral [PSe4]3-building block. Inorg. Chem. 2000, 39, 1525-1533.

48. Huang, F.Q.; Mitchell, K.; Ibers, J.A. New layered materials: syntheses, structures, and optical and magnetic properties of $\mathrm{CsGdZnSe} 3, \mathrm{CsZrCuSe} 3, \mathrm{CsUCuSe} 3$, and BaGdCuSe3. Inorg. Chem. 2001, 40, 5123-5126.

49. Zweibel, K.; Mitchell, R. In CuInSe 2 and CdTe: Scale-Up for Manufacturing; 1989, SERI Publication, prepared for US DOE underContract No. DE-AC02-83CH10093.

50. Tillinski, R.; Rumpf, C.; Näther, C.; Dürichen, P.; Jess, I.; Schunk, S.A.; Bensch, W. Synthesis, crystal structures, and optical properties of new quaternary metal chalcogenides of group 5. Cs2AgVS4, $\mathrm{K} 2 \mathrm{AgVSe} 4, \mathrm{Rb} 2 \mathrm{AgVSe} 4, \mathrm{Rb} 2 \mathrm{AgNbS} 4$, and $\mathrm{Cs} 2 \mathrm{AgNbSe} 4 . Z$. Anorg. Allg. Chem. 1998, 624, 1285-1290. 